\title{
密集市街地におけるエネルギー消費および温熱環境の実態調査と 外部温熱環境の解析 \\ A SURVEY ON ENERGY CONSUMPTION AND THERMAL ENVIRONMENT AND ANALYSIS OF THERMAL ENVIRONMENT IN A DENSELY POPULATED URBAN AREA
}

\author{
西村秀彦*, 辻 政 宏*, 鉾井修一**, 西岡利 晃*** \\ Hidehiko NISHIMURA, Masahiro TSUJ, Shuichi HOKOI \\ and Toshiaki NISHIOKA
}

\begin{abstract}
Energy consumption and thermal environment in residential houses in a densely populated area of Osaka were investigated in order to solve energy and environmental problems. The results showed that the energy consumed for cooling is three to four times higher than in the other areas of Japan and that the indoor temperature in the investigated area could rise over $30^{\circ} \mathrm{C}$ in summer without a room air-conditioner. Along with this study, we analyzed the thermal environment in an alley during summer. It was found the incident solar radiation, the heat discharged from air-conditioners, and the air exchange rate between the alley and the upper air space have a great influence on the thermal environment in the alley.
\end{abstract}

Keywords : Densely populated urban area, Energy consumption, Thermal environment, Survey, Alley space 密集市街地, エネルギー消費, 温熱環境, 実態調查, 路地空間

\section{1.はじめに}

近年、エネルギー資源の枯渴、ヒートアイランド現象などの地 球環境問題が染刻になっている。これは、様々な分野において大 量のエネルギーが消費されるようになった結果であるが、特に、 生活水準の向上に伴い、民生用エネルギーの消費は着実に増加の 一途をたどっている ${ }^{1)}$

このような状況に対する打開策として、未利用エネルギーの有 効活用や地域冷暖房等の地域熱供給の研究 2) 3)などが進められ てきた。また、そのための基礎資料として施設を用途ごとに分類 し、各施設のエネルギー使用量などに関するデータベースが整備

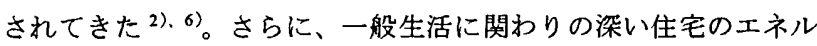
ギー消費に焦点を絞った調查も行われている $\left.{ }^{7} \sim 12\right) 。$

上述の研究 2)、6）～12）では、仕事場と住宅が兼用になった 複合用途の住宅が密集した市街地は対象とされていないが、この 種の既存住宅地は多くの都市に見られ、今後の都市の再開発にお いても有効に利用すべきストックとして保存・再生が望まれるも のである。したがって、このような地域のエネルギー消費や温熱 環境の実態を把握することは、種々の将来予測や都市の在り方を 検討する際に重要になってくると考えられる。

以上の観点より、本研究では、(1)大阪市西成区の密集市街地に おいてエネルギー消費及び温筀環境の調查を行い、現状を把握し、
(2)この調查通して明らかにされた問題のうち、特に夏期の路地空 間の温熱環境をとりあげ、(1)の調查結果を用いて対象地域に関す る温熱環境の解析を行い、空調排熱が及ぼす影響を推定するとと もに、改善策について検討することを目的とする。

\section{2.エネルギー消費の実能調査}

\section{2-1.調査項目と調査方法}

調査対象は、大阪市内の密集市街地にある住宅である。対象地 域と西成区、大阪市の人口密度と世帯密度 ${ }^{13)}$ を表 1 に示す。人 口密度、世帯密度とも大阪市の 2 倍弱となっている。

対象地域にある 70 戸の住戸の承諾を得て、1996 年 12 月〜1998 年 2 月（ガスは 1 月）の電力・ガス消費量データを、関西電力・ 大阪ガスから入手した。

また、1998 年 1 月と 1999 年 8 月に、住戸の特性を把握するた めのアンケート調査を行った。

1998 年 1 月の調查内容は、住宅の構造、種別(戸建て住宅·集合 住宅)、筑年、延べ床面積、居住者人数、住戸平面図、空調機器・給 湯機器·府房機器·家電機器の保有台数、使用頻度、1日あたりの 使用回数、1 回あたりの使用時間などであり、13 戸から回答を得た。

1999 年 8 月の調查では、住宅の用途・構造・階数・室数・延べ 床面積、居住者数、クーラー保有台数、風呂の有無、年間灯油消

\footnotetext{
本論文は第 1 回近幾環境工学シンポジウム(主催：日本建築学会近畿支部・環境工学部会, 1999.10.28)での発表に加筆・修正したものである。

* 京都大学大学院工学研究科修士課程

** 京都大学大学院工学研究科教授. I博

*** 大阪市立大学工学部 教授.工博 
費量などを調べ、38戸から回答を得た。

趣 1 . 1 口・世带密度比皎

\begin{tabular}{|c|c|c|c|c|}
\hline & & $\begin{array}{l}\text { 調㚗就像地区 } \\
\text { (約 25ha) }\end{array}$ & $\begin{array}{r}\text { 西成区 }{ }^{13} \\
\text { (735ha) }\end{array}$ & $\begin{array}{l}\text { 大阪茾 }{ }^{13} \\
(22,127 \mathrm{ha})\end{array}$ \\
\hline 人口密度 & {$[\mathrm{l} / \mathrm{ha}]$} & 216 & 191 & 118 \\
\hline 世荡密榣 & [世茾/ ha & 89 & 102 & 50 \\
\hline
\end{tabular}

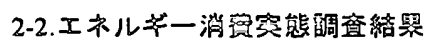

1997 年 1 12 月の月別の電力・ガス消費量データと 1999 年 8 月のアンケート調盆での年間灯油消費量に関する回答から、对象 地域におけるエネルギーの年間消費量、月別消費量 (電力・ガス)、 用途別（冷暖房用）消費量について検討する。

なお、年間エネルギー消費量と椧暖房用エネルギー消費量の検 討の際、対象地域との比較に用いる大阪市の住宅平均 ${ }^{10}$ （以下大 阪市と呼ぶ）、全国の住宅平均 11)、12)（以下全国）、曺京都の住宅 平均 11)、12) (以下東京都) のデータには、表 2 に示すように調㚗 年度に違いがある。また、本論文では 2 次エネルギー換算で評価 する。各エネルギーの換算に用いた值 ${ }^{2)}$ を表 3 に示寸。

2 回のアンケート調查から得られた 38 戸の平均延べ床面積と 平均居住人数を、居住専用住宅（以下専用住宅） 24 戸、仕事場併 用住宅（以下併用住宅）14 戸、全体 38 戸について表4k示寸。

（1）間エネルギー消费量

1997 年の調査対象地域における年間消費量平均と大阪市 ${ }^{10)}$ 、 全国 ${ }^{11}$ 、東京都 ${ }^{11}$ と等比較を図 1 に示寸。尃用住宅 24 戸、併用 住宅 14 戸についても、各々平均をとって示した。

調㚗年度に違いがあるため年間エネルギー消費量伸び率（2〜 $3 \%)^{1)}$ を考慮すると、対象地域の専用住宅の電力消費量は、大阪 市や東京都とほぼ同程度、全国よりやや多い程度となる。ガスに 関しては、大阪市と全国のほぼ中間となっている。大阪市に比べ て消費量が少ないのは、対象地域では風呂を備えていない住宅が 多い (専用住宅の $1 / 3$ 注) ためと考えられる。灯油に関して見ると、 全国よりかなり少なく、大阪市と東京都の間にある。ただし、灯 油㹥電力やガスのようにどの住宅でも使用している訳ではなく、 ある程度の消費がある住宅と全く使用しない住宅とに分かれてい る。サンプル数が少ない本調査では、注意が必要である。エネル ギー 3 種穎の合計で見ると、全国、東京、大阪市と比較して 1 2 割程度少ない（年間エネルギー消費伸び率考慮）ことがわかる。

専用住宅と併用住宅の違いをみると、電力、ガス、灯油のいず れについても併用住宅は専用住宅の約 2 倍の消費量となっている。

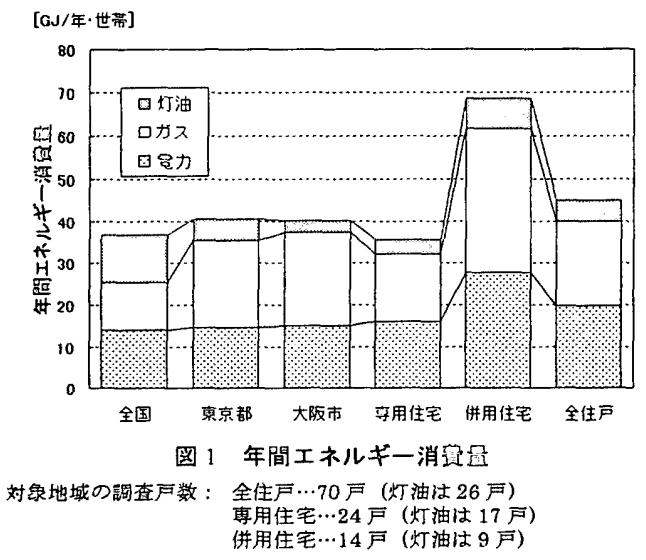

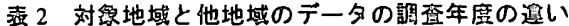

\begin{tabular}{|c|c|c|c|c|c|c|}
\hline & 対象地城 & & 大阪市 ${ }^{10)}$ & & 京都 ${ }^{11)}$.12) & 全国 ${ }^{111.12)}$ \\
\hline 眮卒年度 & 1997 年 & & $90 \sim 1995$ 年の平均 & & 1992 年 & 1992 年 \\
\hline \multicolumn{7}{|c|}{ 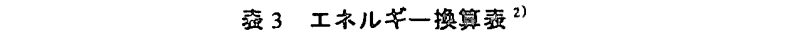 } \\
\hline \multirow{2}{*}{\multicolumn{3}{|c|}{ 科穎 }} & \multicolumn{4}{|c|}{ 換筫值 $[\mathrm{kJ}](\mathrm{kcal})$} \\
\hline & & & \multicolumn{2}{|l|}{1 次 } & \multicolumn{2}{|c|}{2 次 } \\
\hline \multicolumn{2}{|l|}{ 雽力 } & {$[\mathrm{kWh}]$} & \multicolumn{2}{|l|}{$9,419(2,250)$} & \multicolumn{2}{|c|}{$3,600 \quad(860)$} \\
\hline \multicolumn{2}{|c|}{ 都市ガス(13A) } & {$\left[\mathrm{m}^{3}\right]$} & \multicolumn{2}{|l|}{$46,046(11,000)$} & \multicolumn{2}{|c|}{ 同左 } \\
\hline \multicolumn{2}{|l|}{ 灯油 } & L] & \multicolumn{2}{|l|}{$37,255(8,900)$} & \multicolumn{2}{|c|}{ 同左 } \\
\hline
\end{tabular}

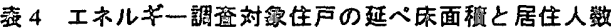

\begin{tabular}{|l|c|c|c|}
\hline & $\begin{array}{c}\text { 要用住宅 } \\
(24 \text { 户 })\end{array}$ & $\begin{array}{c}\text { 併用住宅 } \\
(14 \text { 戸 })\end{array}$ & $\begin{array}{c}\text { 全体 } \\
(38 \text { 户 })\end{array}$ \\
\hline 延べ床面和 $\left[\mathrm{m}^{2} /\right.$ 世带 $]$ & 65.8 & 92.2 & 75.5 \\
\hline 居住人数 $\left[\mathrm{m}^{2} /\right.$ 世带 $]$ & 2.96 & 3.07 & 3.00 \\
\hline
\end{tabular}

\section{（2）日别エネルギー消靦圔}

対象地域における電力、ガスの月別消費量を、専用住宅（24 戸)。併用住宅 (14戸)・全住戸(70戸) に分けて図 2、3 に示寸。 月別電力消費量ではいずれの場合においても、8月と 1 月に李 節のピークが明睹にみられる。専用住宅と併用住宅を比較すると、 両者の比率はもっとも大きい 10 月で約 2.03 倍、小さい 2 月で約 1.43 倍となっているが、年間変動パターンは類似している。

月別平均ガス消費量では、いずれの住戸においても冬期のみ季 節のピークが現れ、冬を最高、夏を最低にほぼ一定の割合で変化 している。1998 年のアンケート調査では、ガスを暖房に使用して いたのは 1 戸のみであったことも考慮すると、冷暖房に用いられ ているガスの割合は低く、ガス消費量の変動に影響を与えている のは給湯であると推定される。専用住宅と併用住宅の比率を比較 すると、もっとも違いの大きい 6 月で約 2.20 倍、小さい 2 月で約 1.98 倍であり、年間変動の形態は似ている。

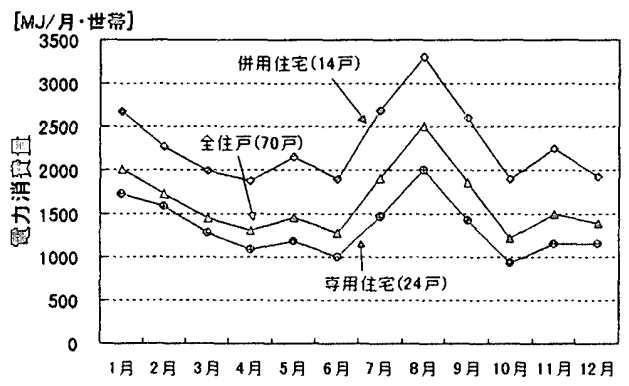

图 2 月别雷力洕留霞(1997 年)

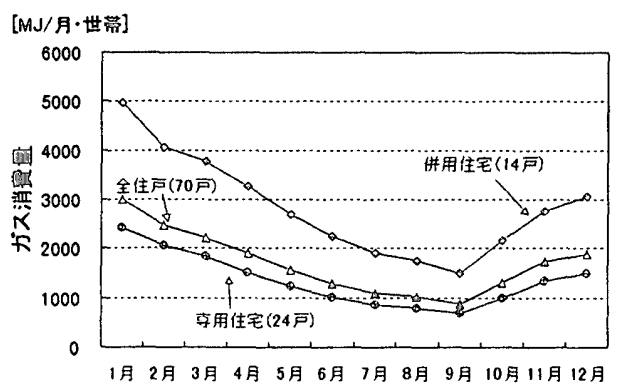

图3月別ガス消邀盈(1997 年)

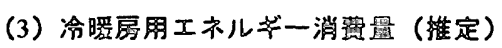

椧暖房用エネルギーの推定を行う。泠房用エネルギーとしては、 電力のみが使用されていると考え、差引法 2)、6－9，12）用いて 推定した。暖房には電力と灯油が使用されていると考え、差引法 を用いて推定した暧房用電力消費量とアンケート調查より得た灯 油消費量の合計を暖房用エネルギーとしている。ガスについては、 1998 年に行ったアンクート調筫で暖房に使用していると回答し 
た住戸が極めて少なかったことと、前述の月別消費量の変動から、 対象地域においては泠暖房用エネルギーとしてほとんど使用され ていないと考えら机るので、ここでは除いて処理している。対象 地域の住宅と大阪市 ${ }^{10)}$ 、全国 ${ }^{12)}$ 、東京都 ${ }^{12)}$ を比較した結果を図 4 に示す。

冷房用エネルギー消費量について、大阪市、全国、東京都の結 果を見ると、大阪市は全国や東京都に比べて約 3 倍の消費量にな っている。対象地域の専用住宅は大阪市よりもさらに消費量が多 く、全国の 3.6 倍、東京都の 3.1 倍である。併用住宅では専用住宅 の約 1.5 倍となっている。対象地域での椧房用エネルギー消費が、 他地域に比べて非常に多いことがわかる。

暖房用エネルギー消費量について見ると、椧房用エネルギーと は逆に、大阪市は全国や東京都の約 $2 / 3$ の消費量になっている。 対象地域の専用住宅は大阪市の約 $2 / 3$ 、全国や東京都の半分程度 である。併用住宅は専用住宅の約 1.6 倍であり冷房用と同程度の 比率となっている。ガスを除いていることを考慮しても、対象地域では 暖房用エネルギー消費が他地域に比べると少ないことがわかる。

なお、冷暖房以外に使用されているエネルギーについては、他 地域とそれほど大きな違いは見られなかった。

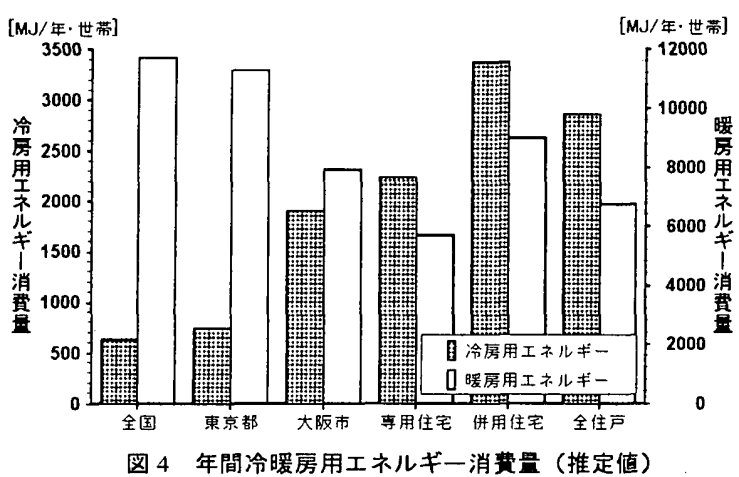

以上のように、対象地域の専用住宅におけるエネルギー消費量 についてみると、年間消費量は、エネルギーの種類によって若干 違いはあるが、トータルでは他地域よりやや少ない程度で大きな 差異は見られなかった。冷暖房用以外のエネルギー消費量につい ても同様に大きな差異は見られなかった。しかし、冷房用エネル ギーについては東京都、全国の 3 倍程度である大阪市よりもさら に多く、暖房用エネルギーは東京都、全国の $2 / 3$ 程度である大阪 市のさらに $2 / 3$ 程度と著しく異なる結果となった。このことから、 対象地域の夏期はかなり高温で過ごしにくく、逆に冬期も高温で 暖房消費が少なくなっているものと考えられる。

また、併用住宅のエネルギー消費は、エネルギーの種類や用途に より若干の差はあるが、専用住宅の約 2 倍と捉えることができる。

\section{3.温熱環境実態調查 \\ 3-1.調查概要}

この調査は、1998 年 2 月上旬より継続しているものである。13 戸の住戸を対象に、生活の中心となる部屋（一部住戸は例外）に 温湿度計を設置してもらい、30 分間隔で計測している。測定住戸 の主な特性を表 5 に示す。今回は冬期・夏期に関して、温度と絶 対湿度の時刻別值をプロットしその相関を見るとともに、時系列
変化についても検討する。なお、いずれも大阪管区気象台観測の 外気温湿度と比較しつつ、測定住戸の温熱環境について考察する。 測定期間は住戸間で多少異なるが、住戸同士の室内温熱環境の単 純比較ではなく、外部環境と室内温熱環境との関係という観点よ り検討するため、測定期間の違いが及ぼす影響はそれほど大きく ないと考えた。

ここでは、各期において測定住戸に多く見られた性状を平均的 に示した住戸A を中心に、それと差異の見られた住戸を取りあげ ている。なお、平均温度（表 6）を見ると住户 $\mathrm{A}$ は夏・冬とも他 住戸に比してやや高いが、その変化特性、外気との相対関係を見 ると一般的と考えられる。

表 5 測定対象住戸の主な特性

\begin{tabular}{|c|c|c|c|c|c|c|c|c|}
\hline \multirow[t]{2}{*}{ 住户 } & \multirow[t]{2}{*}{ 籍造 } & \multirow[t]{2}{*}{ 䧄数 } & \multirow[t]{2}{*}{ 椠年 } & \multirow{2}{*}{$\begin{array}{c}\text { 延へ休面積 } \\
{\left[\mathrm{m}^{2}\right]}\end{array}$} & \multirow{2}{*}{$\begin{array}{c}\text { 居住人数 } \\
{[\text { [ᄉ] }}\end{array}$} & \multirow[t]{2}{*}{ 住宅の角途 } & \multicolumn{2}{|c|}{ 測定期间 } \\
\hline & & & & & & & 冬期 & 夏期 \\
\hline A & 木造 & 3 & - & 87 & 4 & 居住覃用 & $2 / 6 \sim 3 / 31$ & $7 / 1 \sim 8 / 31$ \\
\hline B & 木造 & 2 & S52 & 78 & 4 & 居住耳用 & $2 / 7 \sim 3 / 31$ & $8 / 24 \sim 8 / 31$ \\
\hline c & 木造 & 3 & $\mathrm{H} 1$ & 120 & 4 & 居住真用 & $3 / 11 \sim 3 / 31$ & $7 / 1 \sim 8 / 28$ \\
\hline$D$ & 木造 & 1 & - & 16.2 & 1 & 居住軿用 & $2 / 5 \sim 3 / 31$ & $8 / 24 \sim 8 / 31$ \\
\hline$E$ & \begin{tabular}{|c|} 
木造 \\
+ +鉄需造 \\
\end{tabular} & 3 & $\mathbf{5 5 9}$ & 108 & 4 & 居住更用 & $2 / 5 \sim 3 / 31$ & $7 / 1 \sim 8 / 24$ \\
\hline $\mathrm{F}$ & - & - & - & - & - & 居住南用 & $3 / 11 \sim 3 / 31$ & $7 / 1 \sim 8 / 24$ \\
\hline$G^{* 2}$ & 铁角造 & 4 & $\mathrm{H} 2$ & 160 & 7 & 鱽食店 & $2 / 5 \sim 3 / 31$ & $7 / 1 \sim 8 / 24$ \\
\hline $\mathrm{H}$ & 木造 & 3 & 545 & 43.2 & 3 & 豆腐店 & $2 / 12 \sim 3 / 11$ & $7 / 1 \sim 8 / 24$ \\
\hline 1 & 木造 & 2 & $\mathrm{H} 8$ & 59.5 & 5 & 皮革加工 & $2 / 12 \sim 3 / 31$ & $7 / 1 \sim 8 / 24$ \\
\hline$J^{* 33}$ & - & - & - & - & - & 酒店 & $2 / 5 \sim 3 / 31$ & $7 / 1 \sim 8 / 31$ \\
\hline $\mathrm{K}$ & 木造 & 2 & - & $=$ & 2 & 文具店 & $3 / 11 \sim 3 / 31$ & $7 / 1 \sim 8 / 24$ \\
\hline $\mathrm{L}$ & 木造 & 3 & 542 & 108 & 3 & 鱽英店 & $2 / 26 \sim 3 / 11$ & $7 / 1 \sim 8 / 31$ \\
\hline $\mathrm{M}^{\text {k4t }}$ & - & - & - & - & - & 自動軎整嚾 & $2 / 5 \sim 3 / 31$ & $7 / 1 \sim 8 / 24$ \\
\hline
\end{tabular}

表 6 各期の平均室温 (13 戸平均と住戸A)

\begin{tabular}{|c|c|c|}
\hline & 13 戸平均 & 住戸 $\mathrm{A}$ \\
\hline 冬期 $(2,3$ 月 $)$ & $16.4^{\circ} \mathrm{C}$ & $18.4^{\circ} \mathrm{C}$ \\
\hline 夏期 $(7,8$ 月 $)$ & $29.2^{\circ} \mathrm{C}$ & $30.4^{\circ} \mathrm{C}$ \\
\hline
\end{tabular}

\section{3-2.温熱環境実態調査結果}

\section{（1）冬期（1998 年 2 月）}

住戸Aでは外気に比べて高温高湿であった（図 5 左）。他の住 戸もほとんどが同様の性状を示した。絶対湿度がかなり高くなっ ているのは、灯油式等の開放型暖房器具を用いているためと考え られる。電気式の暖房器具を主に用いている住戸では、これほど 高い絶対湿度は見られなかった。住戸Aの温湿度の時系列変動(図 6 上、7 上）を見ると、外気温変動と異なり室温変動には一日に複 数のピークが見られる。室温上昇時に室内絶対湿度も急激に上昇 している。これも灯油式等の暖房の影響と推定される。

一方、住戸Dでは外気と大きな差がない（図 5 右）。時系列変 動からも、終日低温であることが伺える(図6下)。アンケート調 査によると、住戸D では暖房は電気ストーブ 1 台のみによっで行 われており、局所的な採暖により生活しているものと考えられる が、適切な温熱環境が形成されているとは言い難く、改善の必要 があるものと思われる。

（2）夏期（1998 年 8 月）

住戸Aでは、室内の絶対湿度に外気よりもかなり低い值が見ら れる(図 8 左)。他の 12 戸のうち11 户でもこのような低い值が見 られた。これは、冷房運転が行われているためと推定される。冷 房の使用頻度は住戸により様々であるが、専用住宅よりも併用住 宅で多用されている傾向が見られた（住戸Aでは室温が外気温と 
同程度まで上昇しているが、調査対象地域における路地の昼間の 気温は気象台観測值よりも $2 \sim 3^{\circ} \mathrm{C}$ 高い $\left.{ }^{14}\right)$ )。時系列変動 (図 9 上、 10 上）を見ると、外気温が上昇中に室温は下降し始め、それと同 時に室内の絶対湿度も急激に低下している。この時点で冷房使用 が開始されたと推定される。冷房が使用されていないと推定され る時間帯では、30ㄷを上回っていることが多い。

住戸Cでは、室内の絶対湿度に著しく低い值は見られない（図 8 右)。時系列変動（図９下、10下）を見ると、室温変動は外気温 変動が緩和された形状となっており、絶対湿度については外気と 室内に大きな差異は見られない。したがって、住戸Cでは冷房が

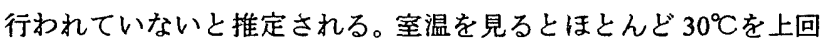
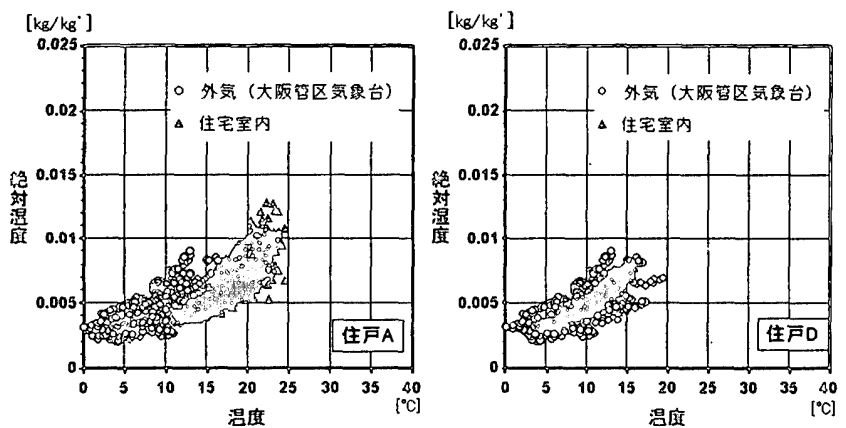

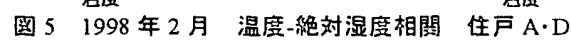
[०c]
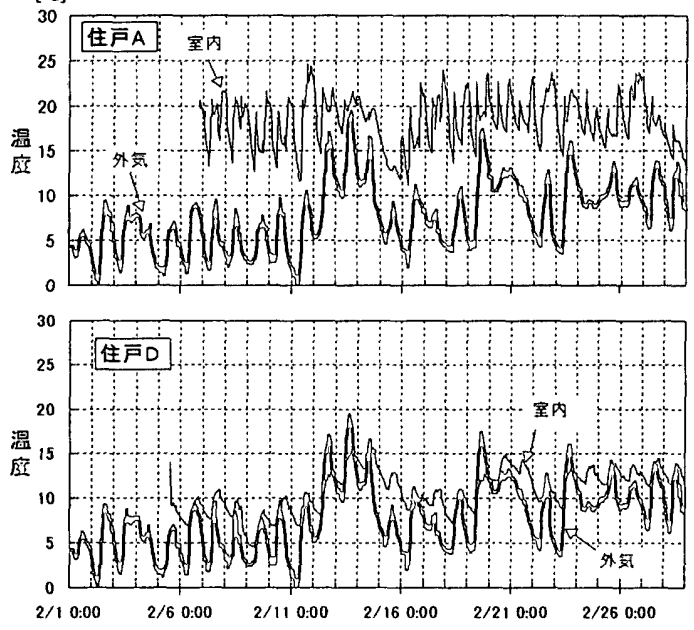

图 6 温度比洂（外氮・空内）1998 年 2 月 住戸 A.D

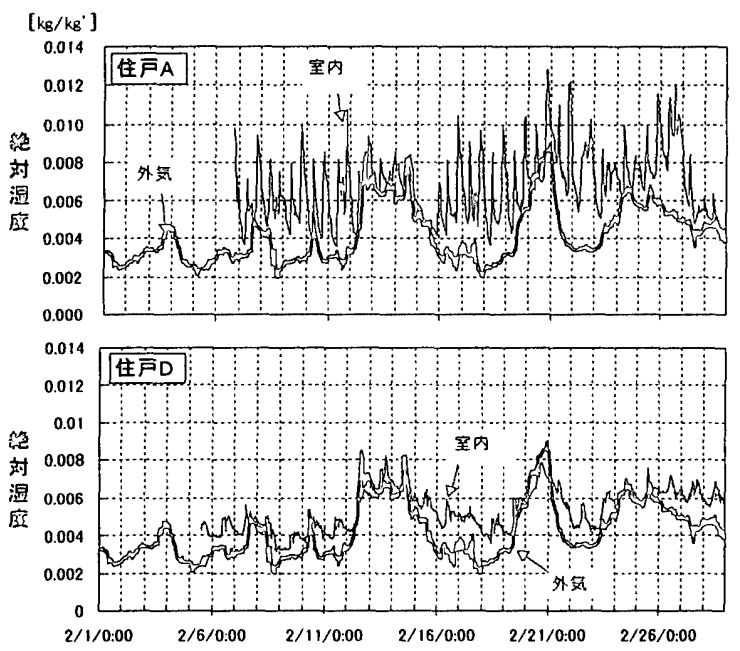

图 7 絶対湿度比皎（外茋・室内）1998年 2 月 住戸 A.D
っている。

以上のように、冬期・夏期の対象地域の温就環境を見ると、冬 期には一部住戸において改善が必要と考えられるが、全体として は良好な温就環境にあると言える。一方、夏期には椧房を使用し

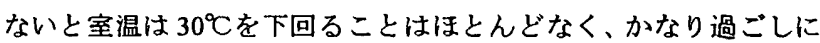
くい温就環境であると考えられる。 §2 のエネルギー消費実態調 㚗で明らかになった「対象地域では泠房用エネルギー消苟量が非 常に多いとという結果も、夏期の温熱環境が良好ではないという ことと表裹一体をなしているものと考えられる。何らかの改善策 が必要な課題と言えよう。
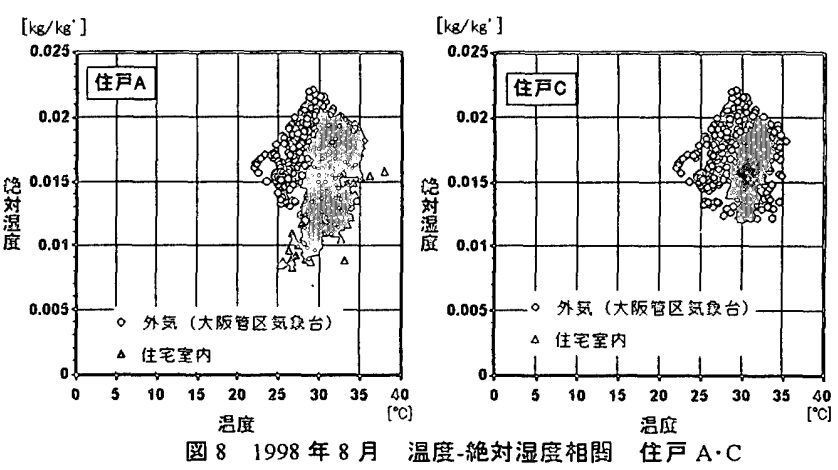

$\left[{ }^{\circ} \mathrm{C}\right]$

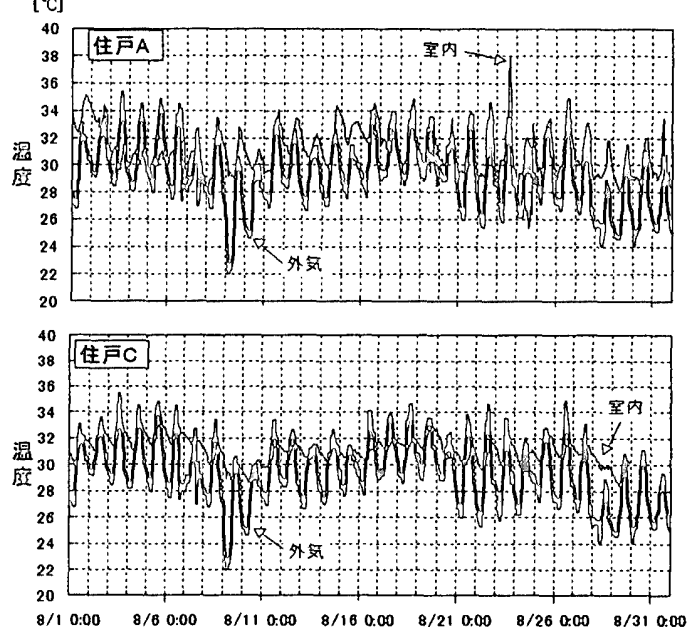

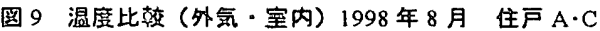

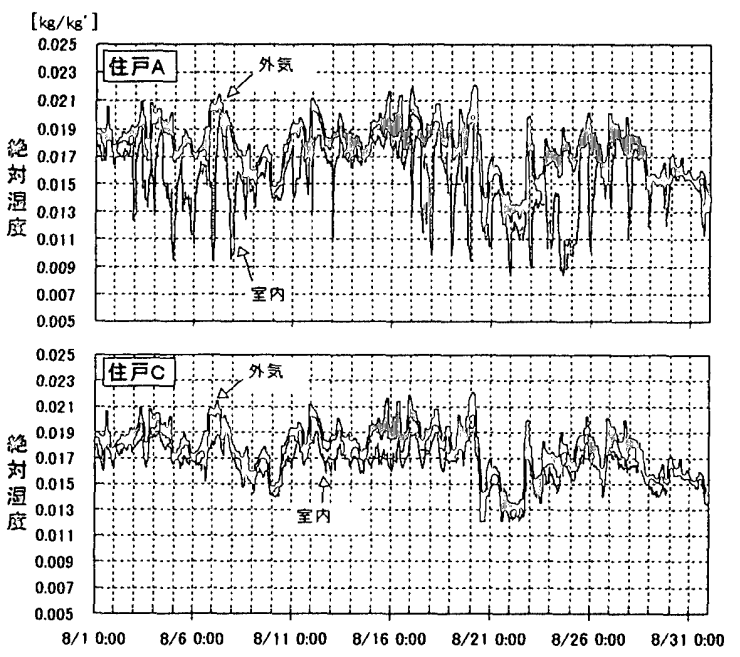

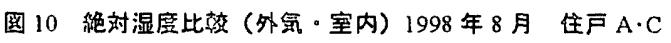




\section{4.路地空間の温熱環境解析}

§2のエネルギー消費量の赛態調查より、対象地域での夏期の 椧房エネルギー消費量が非常に多く、逆に冬期の暖房用消費量が 少ないこと、ミ3 の温熱環境調査では、対象地域における夏期の 室内環境は必ずしも快適な状態とは言えないことが明らかにされ た。また、文献 14）によると、対象地域の路地で測定された外気 温は気象台観測值よりも $2 \sim 3^{\circ} \mathrm{C}$ 高く、室内環境悪化の一因となっ ていると考えられる。冷房用エネルギー消費量が他地域に比べ著 しく多いのは、「屋外空間の暑さ 一冷房用エネルギー消費量の增 大」という単純な因果関係だけではなく、「外部環境の暑さかクー ラーの使用 $\rightarrow$ 屋外人の排熱 $\rightarrow$ 外部環境の悪化」という悪循蕀の形 成によるものと考えられる。したがって、この問題を解決するに は宔内温熱環境の改善だけでなく、周囲の外部環境も考慮に入れ て改善策を考えていくことが必要となる。

密集住宅地域の再開発においては、集合住宅化とそれに伴う才 ープンスペースの確保という手法がしばしば採用されるが、通風 効果よりも日射の影響が強くなり温熱環境的には必ずしも良くな い14)ことがある。またこうした手法では、これまで長年に渡っ て培われてきた地域の人間関倸が損なわれるおそれがある。資源 の有効利用の観点からも、既存の住宅を可能な限り有効に再生 · 活用していくことが望ましい。以上を考慮すると、路地空間を含 む地域レベルでの温熱環境の改善が有効な方策の一つと考えられ る。

本章では以上のことをふまえて、対象地域のエネルギー・温熱睘境 問題を考える際の基盤となる夏期の路地空間の温熱環境について、 第 2、3 章の調查結果を用いて解析を行い、解析結果を実測結果と比 較検討した上で、路地空間の温熟環境の改善策について考察する。

\section{4-1.解析対象}

本章では、路地空間の温度を均一とみなして非定常熱収支式を 解き、各要因が温熱環境に与える影響を調べる。一般的には、路 地は複雑な幾何学的形状を有する空間であるが、すべての住戸を 同一の直方体に単純化し、路地の両側に同じ戸数だけ連なってい るとする。路地の端の住戸についても他の住戸と同じ条件下にあ るものと考え、路地の側面では熱の流出入が行われないとする。

建物と外部空間を対象とした従来の研究には、二次元長方形市 街地空間 15)，16) や連続覆付歩廊内部 ${ }^{17)}$ にお性る等的性状の解析 と評価を行ったものがある。特に文献 15)、16）では、本研究と ほぼ同じ対象についての詳細な検討がなされているが、本研究で 対象と寸る路地空間より大きな空間を扱っている。また、建物側 と都市大気側の伝熱を連成させたモデルによる詳細な解析 ${ }^{18)}$ 21) も行われている。ただし、これらの研究では、本研究よりも对象 の規模が大きく（入射日射とキャノピー内気流の制御という観点 から寸ると)、建物とその四方の空間を基本構成単位としてそれら が面的に一様に配置されているモデルを用いている。

本研究で扱う対象注、帯状の低層住宅棟と棟間の路地よりなる 地域である。路地は水平方向を住宅群により、下方を地面により 囲われているので、空気の流出入はほぼ上空との間のみと考える ことができる。本論文においては、この空気の流動を路地空間と 上空との間の仮想的な換気により行われるとして解析している。 なお、この場合に用いるべき仮想換気回数は多くの要因により左 右され、路地空間内での気流分布と密接に関係するため、同一形
状モデルを用いた気流解析の結果 ${ }^{25)}$ から近似的に定めている。

本論文中で使用するモデルと記号を図 11 に示す。なお、図中 の $\theta_{s w} 、 Q_{w} 、 Q_{v} 、 Q_{i w}$ については、路地の両側で同じ記号を用いて いるが、方位によりそれぞれの側で違う值となる。

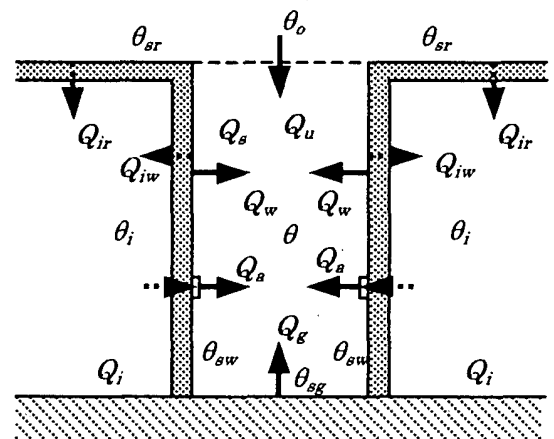

图 11 解析モデルと使用する諸量（路地断面図）

$\theta 、 \theta_{o} 、 \theta_{1}$ : 路地空間、上空、室内の温度 $\left[{ }^{\circ} \mathrm{C}\right] 、 \theta_{s w} 、 \theta_{s g} 、 \theta_{s r}$ : 譬装面、地表面、屋

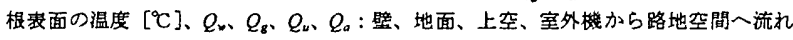
万熟流 $[\mathrm{W}] 、 Q_{s}$ : 路地空間で吸収される反射日射量 $[\mathrm{W}] 、 Q_{w} 、 Q_{r r}$ : 壁、屋根を通

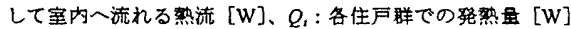

\section{4-2.路地空間空気の熱収支式}

$c \gamma d \frac{\partial \theta}{\partial t}=Q_{w}+Q_{g}+Q_{u}+Q_{a}+Q_{s}$

$c \gamma$ : 空笑の容楼比熱 $\left[\mathrm{J} / \mathrm{m}^{3} \mathrm{~K}\right] 、 V:$ 路地空問の体糟 $\left[\mathrm{m}^{3}\right] 、 t:$ 時間 $[\mathrm{s}]$

ここで、熱流 $Q_{w} 、 Q_{g} 、$ 及び室内人の流入熱流 $Q_{i w} 、 Q_{i r}$ は次式 で与えられる。

$$
\begin{aligned}
& \text { 壁から路地への熱流 : } Q_{w}=S_{w} \alpha_{o}\left(\theta_{s w}-\theta\right) \quad \cdots(2) \\
& \text { 地面から路地への熱流 : } Q_{\boldsymbol{g}}=S_{\boldsymbol{g}} \alpha_{o}\left(\theta_{s g}-\theta\right) \quad \cdots(3) \\
& Q_{i w}=S_{w} K_{w}\left(\theta_{\text {solw }}-\theta_{i}\right) \\
& Q_{i r}=S_{r} K_{r}^{\prime}\left(\theta_{\text {solr }}{ }^{\prime}-\theta_{i}\right)
\end{aligned}
$$

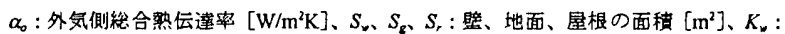

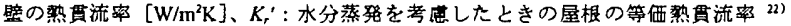

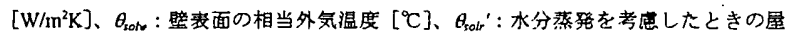
根表面の相当外気温度 $\left.{ }^{22}{ }^{20} \mathrm{C}\right]$

壁表面の温度については、近似的に定常状態として取り扱い、 次式から求める。

$$
\alpha_{o}\left(\theta_{\infty N ⿻}-\theta_{\infty}\right)=\frac{1}{1 / K_{\omega}-1 / \alpha_{o}}\left(\theta_{m}-\theta_{i}\right)
$$

地表面の温度は、深さ $5 \mathrm{~m}$ の地点で地盤温度が $15^{\circ} \mathrm{C}$ 一定に保た れているとした。ただし、地表面においては水分蒸発も考慮する。

路地空間と上空での熱の交換については、仮想換気回数を設定 し、次式によって計算する ${ }^{25)}$ 。

$Q_{u}=n c \gamma V\left(\theta_{o}-\theta\right)$

$n:$ 路地空間々路地上㞬間の仮想换気回数 $[1 / \mathrm{h}]$

室外機からの排熱量は、冷房負荷（外気から室内へ流入する熱 量と室内での発熱量の和）と冷凍機の運転に必要な熱量の和であ るから、次のように表すことができる。

$$
Q_{a}=\left(Q_{i w}+Q_{i r}+Q_{i}\left(1+\frac{1}{C O P}\right)\right.
$$

$C O P$ : 冷凍機の成綪保数 [-]

また、壁や地面で 2 回目に反射される日射量は寸べて路地空間 の空気に吸収されるとする。これが（1）式中の $Q_{s}$ である。 


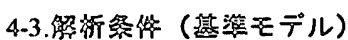

外気温には大阪の 8 月の値 ${ }^{23)}$ を、日射量としては大阪標淮気 象データを用いる（図 12）。各面への入射日射量は、形態係数を 考慮して計算する。

東西の住戸群はそれぞれ 8 戸から構成されているとし、1 戸の 寸法は間口 $4 \mathrm{~m}$ 、奥行き $10 \mathrm{~m}$ 、高さ $6 \mathrm{~m}$ 、路地の幅は $3 \mathrm{~m}$ と寸る。 住宅の構造は調查対象地域に多く見られた木造とし、壁・屋根の 熟貫流率は文献 24）の值を用いる。各伝達率には以下の数值を用 い、物性値については表 7 に示す。

\section{外気㒋総合熱伝達率 : $\alpha_{o}=23.2\left[\mathrm{~W} / \mathrm{m}^{2} \mathrm{~K}\right]$ \\ 室内側総合热伝逹率 : $\alpha_{i}=9.3\left[\mathrm{~W} / \mathrm{m}^{2} \mathrm{~K}\right]$ \\ 外気䚋湿気伝逹率 $\quad: \alpha_{o}{ }^{\prime}=60.0\left[\mathrm{~kg} / \mathrm{m}^{2} \mathrm{hkg} / \mathrm{kg}{ }^{\prime}\right]$}

各住戸群での室内発熱 $Q_{i}$ については、人体発就 $Q_{i}$ と冷房用以 外 (照明・家電機器等) の電力消費量 $E_{\min }$ を考え、第 2 章の調査 結果をもとに（9）式を用いて定める。

$$
Q_{i}=\left(\frac{\overline{E_{\min }}}{30 \times 24}+Q_{h s} \times R_{m}\right) \times 8
$$

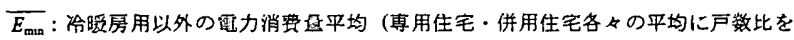

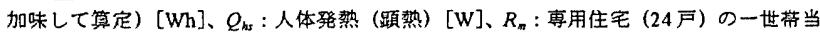
たり平均居住人数 [人]

第 3 章の温效環境調査の結果では、専用住宅と併用住宅で室温 に大きな違いがあるということはなかった。そこで、本解析では 専用住宅の中で 8 月の椧房用エネルギー消費量と冷房用以外の電 力消費量の両方が専用住宅 24 戸の平均に近い住戸を代表的住戸 とみなし、その住戸の 8 月の平均日変動室温を用いた（図 13）。 冷房は、この室温を実現するために使用されるとする（暖房が必 要となる場合は運転しない)。

仮想換気回数については、同一モデルを用いて行われた気流解 析結果 ${ }^{25)}$ から $n=300$ [1/h] とする。また、COP=2.5 [-] とする。 以上の条件を用いて、30日分の非定常計算を行った。
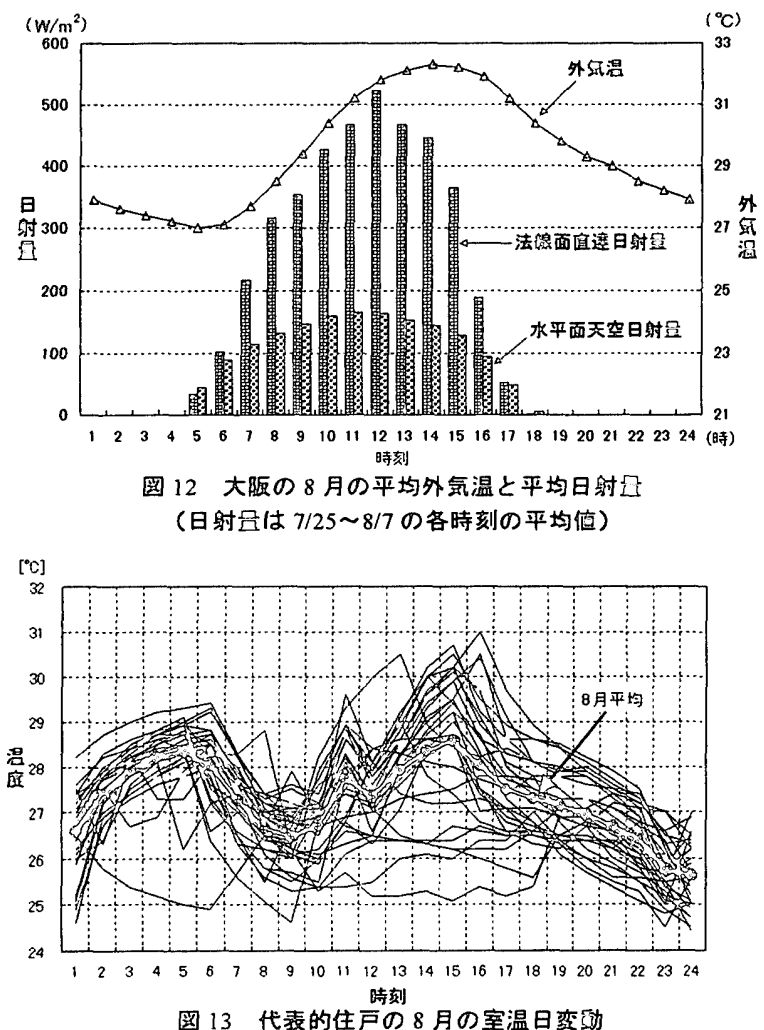

图 13 代埥的住戸の 8 月の室温日变动

\begin{tabular}{|c|c|c|c|c|}
\hline \multicolumn{3}{|c|}{ 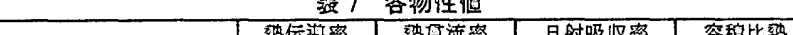 } & & \\
\hline . & 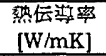 & $\begin{array}{l}\text { 热流流 } \\
{\left[\mathrm{W} / \mathrm{m}^{2} \mathrm{~K}\right]}\end{array}$ & $\begin{array}{c}\text { 日射吸收率 } \\
{[-]}\end{array}$ & $\begin{array}{l}\text { 容楦比熟 } \\
{\left[\mathrm{kJ} / \mathrm{m}^{3} \mathrm{~K}\right]}\end{array}$ \\
\hline 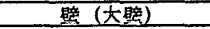 & $=$ & 1.41 & 0.70 & $=$ \\
\hline 屋根 & $=$ & 1.64 & 0.70 & - \\
\hline 地面 $($ アフフルト) & 0.73 & $=$ & 0.85 & 2055.8 \\
\hline$t$ & 0.61 & $=$ & $=$ & 1498.7 \\
\hline 空気 & - & $=$ & - & 1.30 \\
\hline
\end{tabular}

\section{4-4.解新緮腎}

解析は南北方向に延びる路地（今後、南北路地と呼ぶ）と東西 方向に延びる路地（東西路地）について行ったが、路地の方向に よって解析結果が大きく異なることはなかったので、ここでは南 北路地の解析結果を示す。

対象地域にある路地で実測された気温 ${ }^{14)}$ と解析結果を比較し たものが図 14 である。路地気温の解析結果は実測よりも約 $1^{\circ} \mathrm{C}$ 低 い。これは、時間あたりの内部発就として、エネルギー消費量の 月櫝算值を $30[$ 日] $\times 24$ [時間]で除した值を用いたことを考慮し て、計算では日射量、室温、上空温（気象台）にも 8 月の平均を 用いたが、それらは実測が行われた日に比べ小さい値となってい たためと考えられる。そこで、日射量には大阪標準デ一タを実測

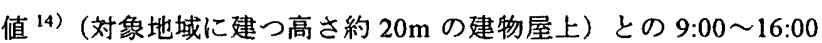
の平均の比率で補正した值を、室温と上空温には $8 / 11$ と $8 / 12$ の 日変動平均を用い、解析を行った結果が図 15 である。得られた路 地気温は、実測とおおむね一致している。このことから、本解析 モデルは非常に簡易化、単純化されたものではあるが、測定対象 地域の温鵁特性を一定程度表現しているものと考えられる。
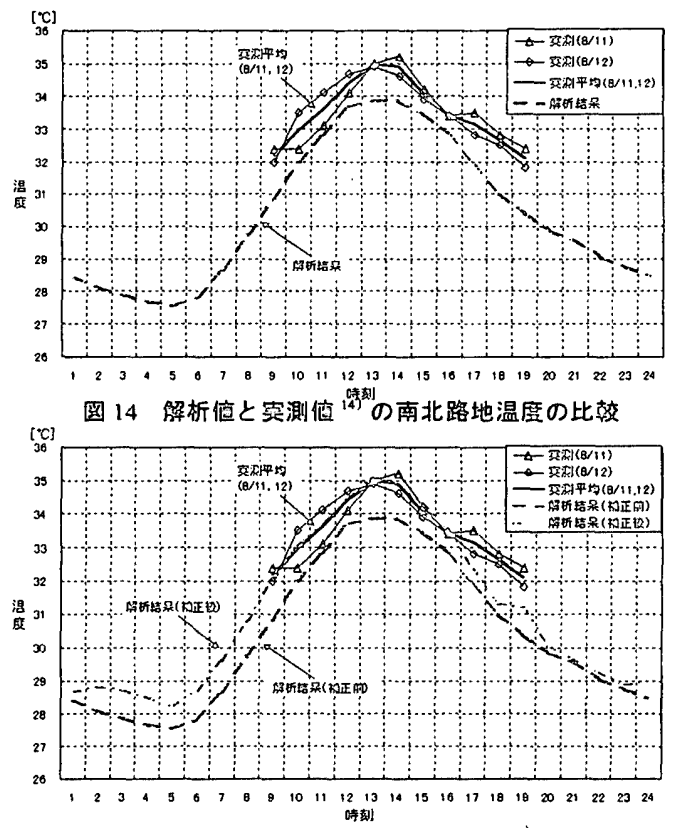

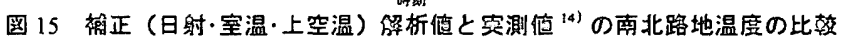

各面に入射寸る日射量をみると、屋根面への入射日射量が非常 に大きいことが分かる（図 16）。壁面や地面の温度は、入射する 日射量の変動に忘じて変化している。日射がない夜間には、地面 の温度だけが外気温よりも高くなる（図 17）。

路地空間に流入する熱量のうち、空調機の室外機から路地空間 一排出される就量は日中に大きな割合を占める（図 18）。室外機 からの排袐が路地空間の温熟環境に与える影響の大きさが同える。

ただし、冷房の使用が増える日中の室外機からの排熱を形成す る最大の要因は、日射によって表面温度が上昇した屋根を通して 室内に流入する熟流であり（図 19）、ここでも日射が大きく影響 
している。上空から路地空間へ流れる熱量は常に負の值（図 18） で、路地空間から上空へ高温の空気が流出することによって、熱 收支が保たれている。路地空間で吸収される反射日射量の割合は 小さく（図 18）、ここで設定した条件下（基準モデル）では、2 回目以降の反射日射量の詳細な検討は必要ない。

路地の方向に関わらず、「各面に入射し、吸收される日射量」 「室外機からの排熱」「上空との空気交換による熱移動」が、路地 空間の温熱環境を大きく支配していると言える。
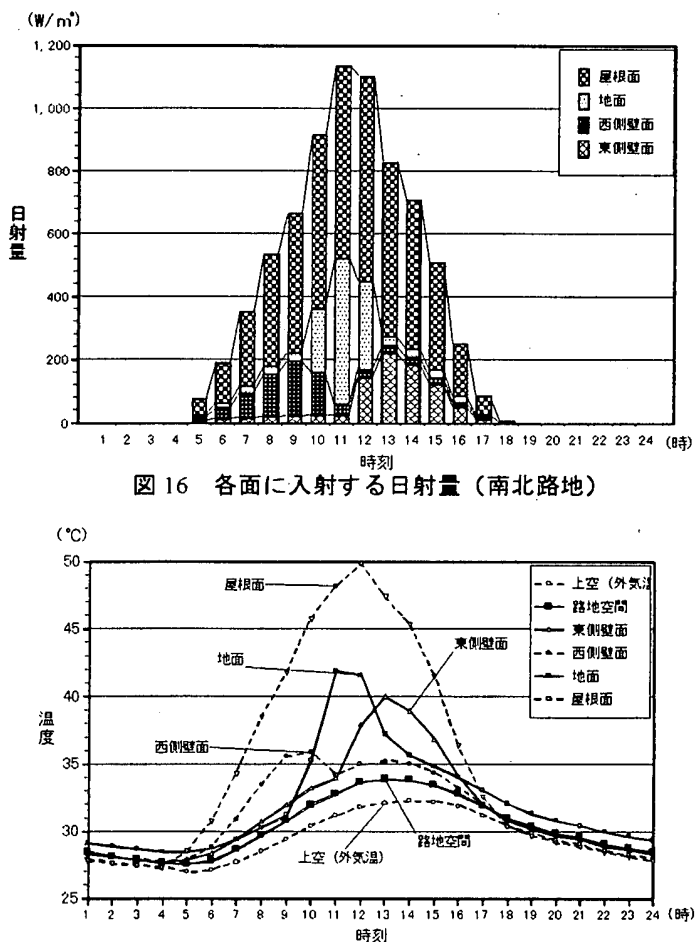

図 17 各部温度の日変化 (南北路地)

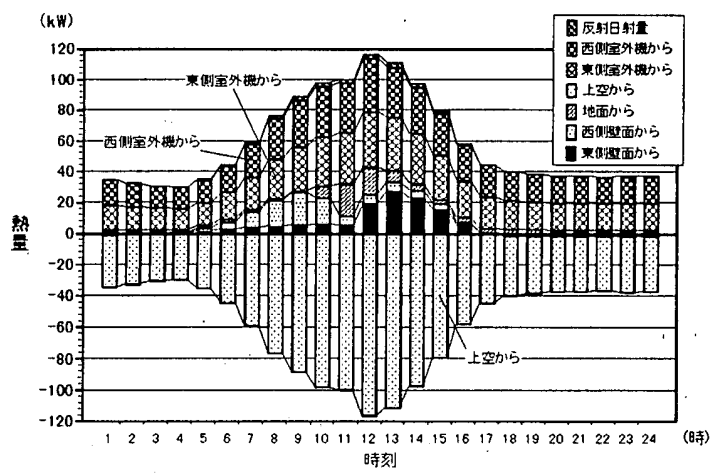

図 18 路地空間に流入する各熱量·(南北路地)

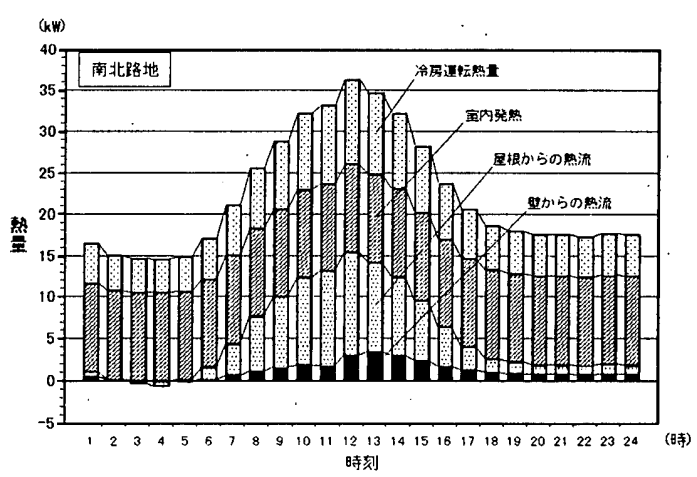

图 19 室外機からの排熱の内訳（南北路地の東側室外機）

\section{4-5.路地温熱環境の改善}

前述の解析モデルに基づき、路地空間の温熱環境改善策を検討 した結果のうち、主なものを以下に示す。いずれも定性的には明 らかなものであるが、簡易なモデルを用いていることに伴う制約 を前提に、定量的な情報を得ることを目的としている。

（1）各面に入射し、吸収される日射量を減少させる。

住宅の路地に面する壁面の上端に水平に $1 \mathrm{~m}$ の庇を設置した場 合の路地空間温度を図 20 に示寸。仮想換気回数の值によって異な る影響が現れる。庇を設置した後の仮想換気回数が基準モデルの 300 回と変わらない場合には、最大で約 $0.6^{\circ} \mathrm{C}$ の路地空間温度の低 下が得られる。しかし通常は、庇を設置すると上空との換気回数 は少なくなるため、設置後の換気回数を精度良く推定する必要が ある。

（2）室外機からの排熱量を減少させる。

室外機加ら排熱の内訳を示す図 19 上り、壁を通して室内に 流入する熱量に比べ、屋根を通して室内に流入する熱量が非常に 大きい。このような地域では、密集していることにより壁への入 射日射量が小さくなるためと考えられる。この特性を考慮すると、 屋根と壁の両方を同程度に断熱するより、屋根の断熱を徹底する ことにより路地空間の温熱環境が大きく改善されることがわかる。

さらに、室外機からの排熱に着目し、地域熱供給システムなど

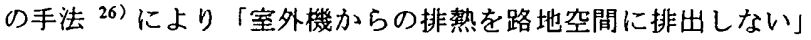
として解析を行うと、日中で約 $1.1^{\circ} \mathrm{C}$ も路地空間温度は低下寸る （図 21）。室外機からの排熱の処理方法を考慮することにより、 路地空間の温熱環境が大きく改善される可能性のあることがわかる。

（3）上空との換気を適切に制御する。

基準状態から「仮想換気回数 $n$ を大きくする」と、路地空間温 度は低下寸る。路地空間と上空間との間の換気に及ぼす上空の風 の影響を考慮して、屋根や庇の設計をする必要がある。ただし、 室外機からの排㷫の処理と庇による入射日射量の制限により、路 地空間の温度を上空の温度よりも低くすることが可能な場合には、 上空との換気はむしろ少ない方が良いと考えられる。

種々の改善案を組み合わせたモデルについての解析も行った （図 21）。室外機からの排熱を0にして、路地空間に流入する熱 量を大幅に減少させた場合、庇を設けることで換気回数が 200 回 に减少しても、路地気温は上空の温度より最大でも $0.3^{\circ} \mathrm{C}$ 高い程度 であり、換気回数の減少によるデメリットはほとんどなく、庇の 日射遮蔽効果が大きくなっている。さらに散水を行うと、路地気 温は上空温度よりも低くなり、庇設置による換気回数减少はプラ スに作用していると言える。

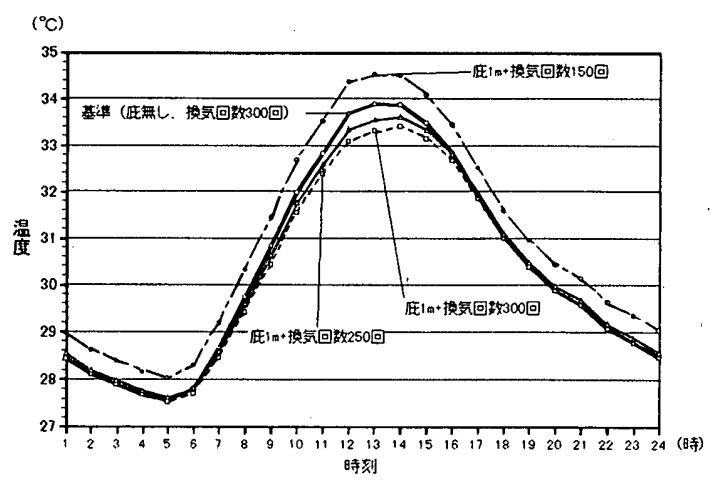

図 20 庇を設倦した埸合の路地空間温度（南北路地） 


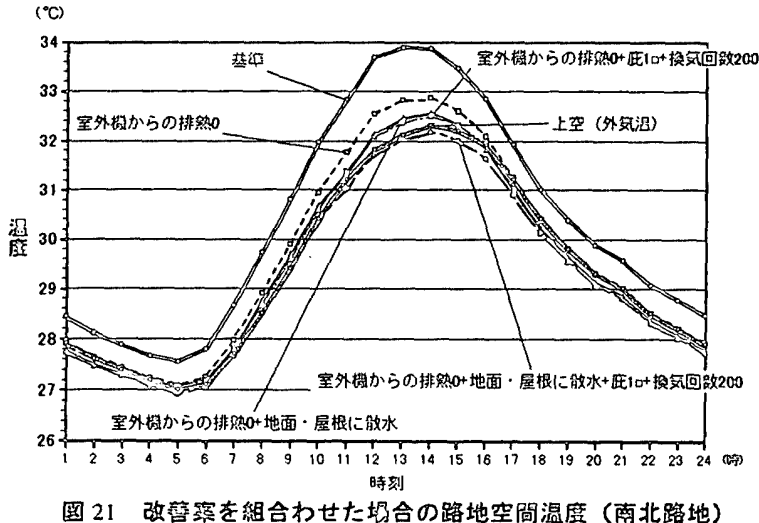

5.さと的

本研究では大阪市の密集住宅地を対象にエネルギー消費及び 温等環境の実態調査を行い、以下のことを明らかにした。

対象地域の専用住宅に㧍けるエネルギー消費量については、年 間消費量では、エネルギーの種類によって若干臬いはあるが、ト 一タルでは他地域よりやや少ない程度で大きな差異は見られない。 椧暖芳用以外のエネルギー消費量についても同様に大きな差異は 見られなかった。しかし、冷房用エネルギーについては、東京都、 全国の 3 倍程度である大阪市よりもさらに多く、暖房用エネルギ 一は東京都、全国の $2 / 3$ 程度である大阪市のさらに $2 / 3$ 程度と著 しく異なる結果となった。また、併用住宅のエネルギー消㰓は、 エネルギーの種穎や用途により若干の逴いはあるが、おおよそ専 用住宅の 2 倍と捉えることができる。

対象地域の冬期、百期の温熟環境については、冬期には一部住 戸において改善が必要と考えられるが、全体としては良好な温就 嘼境にあると言える。逆に、首期には椧房を使用しないと室温は $30^{\circ} \mathrm{C}$ を回ることはほとんどなく、かなり過ごしにくい温热環境 であると考えられる。

以上の調疽結果から明らかとなった夏期の温㛙環境の問題点 を検討するため、調査結果に基づいて路地空間の温熱環境の解析 を行った。その結果、路地空間と路地上空間での空気交換量、路 地空間に入射する日射量、室外機からの排熟（主として屋根を通 して室内へ流入する熱量に由来する）が、路地空間の温法環境を 大きく支配していることがわかった。

路地空間の温就環境の主な改善策としては、

・屋根を断就構造にする（壁の断熟に比べ非常に効界大）。

・室外機からの排就を路地空間に排出しない処理方法を採用 する。あるいは、室外機の位置を路地上部に移動する ${ }^{25\rangle 。 ~}$

・適当な庇を設置する（入射日射量の減少と上空との換気回数 の減少の双方を考慮する必要有り)。

・地面や屋根人の散水を行う。

などが挙げられる。

\section{『謝辞】}

本研究は地域環境計画委員会 (委員長 松本衛) のエネルギー 小委員会の下で行われた研究の一部である。

本調㸖を行うにあたり、街づくり委員会、西成区の調㚗対象住 戸、関西電力、大阪ガスの方々には多大なる協力をいただきまし た。また、東京理科大学井上隆助教授からは嘪重なアドバイスを いただきました。ここに記して感謝の意を表します。

【注】

鉞湯を利用している独立住宅は現在では減少しつつあるが、世带あたりの

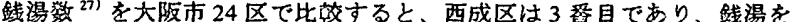

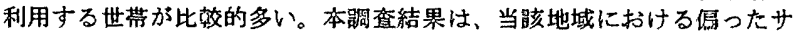
ンプリングに基つくくのではないと推定される。

《參考文嗝】

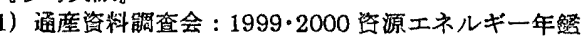

2）西田勝他 : 九州地域における都市・避筑の未利用エネルギー有効利用に

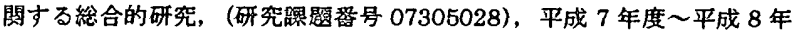

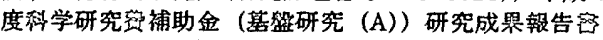

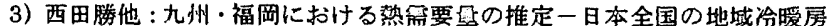

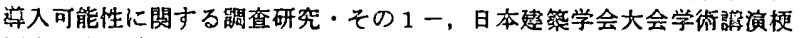

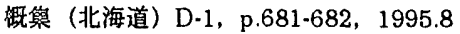

4）下田吉之他: 都市未利用エネルギーの活用可能性評価手法に閣する研究

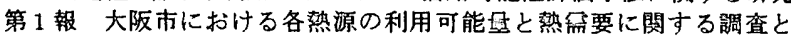

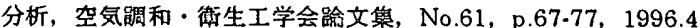

5) 下田吉之他 : 都市末利用エネルギーの活用可能性評価手法に閔する研究 第 2 報 未利用等源水供給ネットワークの省エネルギーポテンシャル，

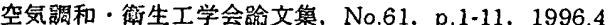

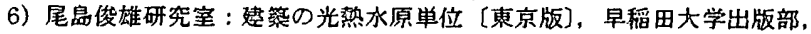
1995.6

7）濢地孝男他 : 用途別エネルギ一消㕘量原単位の算出と推定式の作成 国的䯏亘に基つく住宅のエネルギー消密とライフスタイルに閔する研 究 (第 1 報), 日本娺筑学会計画系踰文報告息, No.462, p.41 48, 1994.8

8）福易逸成他: 九州地域における住宅エネルギー消贸枟造に䦥する研究， 空気調和・衛生工学会踰文集, No.57, p.35.48, 1995.2

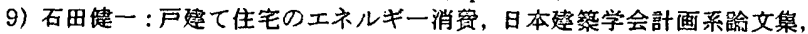
No.501, p.29-36, 1997.11

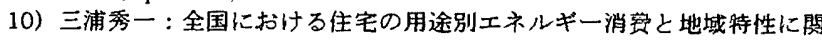
寸る研究, 日本建筑学会計画系踰文隼, No.510, p77-83，1998.8

11）中野勝敏他：查京都における住宅用エネルギー消空実態 その 1 工

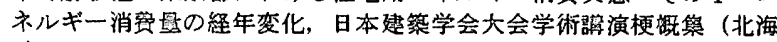
道) D-2, p.213.214, 1995.8

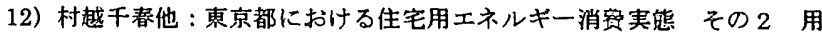

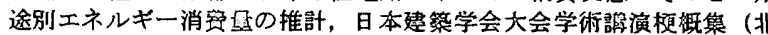
海道) D-2, p.215-216，1995.8

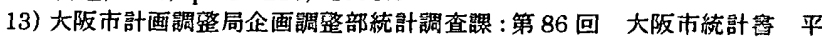
成 10 年版

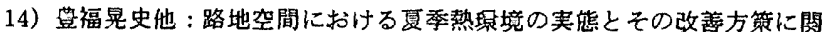

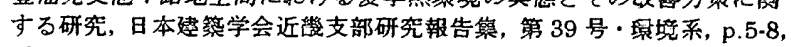
1999.6

15）中村泰人, 平岡久司 : 二次元長方形市街地空間に拈ける表面の温度お 上び热流に関する研究, 日本建筑学会計画系䃋文報告集, No.367, p.8 $\sim 14,1986.9$

16）中村綊人，平岡久司：二次元長方形市街地㞬間の路上にある人体の䓡 負街们閣する解析的研究, 日本建筑学会計画系諭文報告泉, No.369, p.12 21, 1986.11

17）辻原万規彦他：真南アジアを中心に分布する連続待付步㾿内部の泪熱 理境関する研究，日本建筑学会計画系踰立報告篹，No.515，p.105 $\sim 112,1999.1$

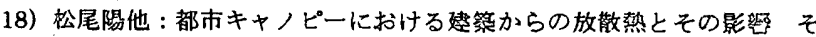

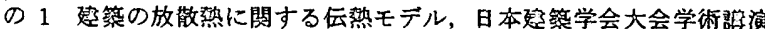

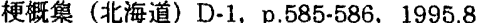

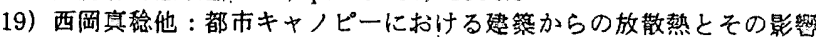

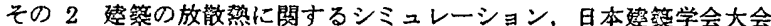
学術椌演梗慨集 (北海道) D.1, p.587.588, 1995.8

20）谷本润他：发筑一都市一土烄連成系モデルによる都市高温化要因の定

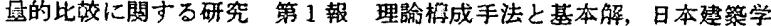
会計画系諭文集, No.504,p87.93，1998.2

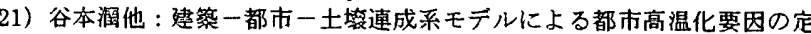

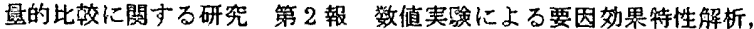
日本建筑学会計画系䃋文监, No.510, p53-60, 1998.8

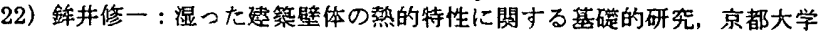
学位諸求踰文, p.169-171，1986.4

23）気像庁：気像庁月報，1998.8

24）日本建築学会：建筑設計资料楅成 1 䶂境，p.123，1978.6

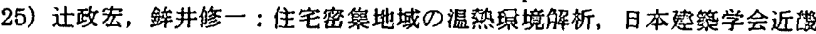
支部研究報告集, 第 39 号・理境系, p.73-76, 1999.6

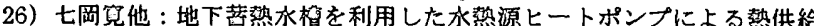

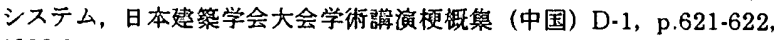
1999.9

27）http://www.os.xaxon.ne.jp / hit/sento.htm\#大阪区域別鐵湯リス

（1999年12月 2 日原稿受理，2000年 5 月16日採用決定 